\title{
Paleoenvironments in China during the Last Glacial Maximum and the Holocene Optimum
}

\author{
1 Department of Earth Sciences, Zhongshan University, 510275 Guangzhou, China \\ 2 Institute of Geology, Chinese Academy of Sciences, Beijing 100029, China \\ 3 Maison Méditerranéenne des Sciences de l'Homme, LAPMO, BP 647, 13090 Aix-en-Provence, cedex 2, France
}

Two key-periods, the Last Glacial Maximum (LGM) and the Holocene Optimum represent respectively the coldest and warmest episodes that were testified in China by a great number of paleoenvironment evidences. At the $L G M$, the climate was colder and drier with the mean annual temperature $7-10^{\circ} \mathrm{C}$ lower than today in the North and $4-6{ }^{\circ} \mathrm{C}$ in the South. The multidisciplinary data are consistent with global changes, such as the depression of snowline, southward advancing of permafrost limit, expansion of loess deposition, lowering of the lake level, invasion to the eastern China of desertic vegetation, displacement to the South of zonal vegetation, many discoveries in temperate climate zone of the northern cold mammals, and the remarkable sea regression resulting in the eastward shift of the Chinese coastal line. The data of Holocene recognized a warm period (ca. 9,000-6,000 yr BP) that the temperature estimates were generally $2-4^{\circ} \mathrm{C}$ higher than nowadays. The rise of sea level resulted in great changes of the coastal environment in eastern China. Due to the warm climate, glaciers largely retreated and even disappeared in the eastern part. The permafrost was located to the North of the current limit. Desert and loess greatly reduced and the highest lake level was found mostly during 9,000-5,000 yr BP. The boreal conifers were to the north of the present locations, and many steppe areas were covered with forested formations. The above past climate and ecological pattern of the key-periods in China helps to better understand the future changes and their results.

\section{Introduction}

A good number of dated observations on the paleoenvironmental conditions in China during the Last Glacial Maximum (LGM) and the Holocene presently exist. However, most of the publications are in Chinese and not available to the greater part of occidental scientists, despite the efforts of a few authors (Shi, 1984; Liu, 1991; An et al., 1991b) who synthesised those data in some international journals. More recently, research by many international scientific groups provided more detailed paleoenvironmental records for some regions of China (Wake and Mayewski, 1996). The Chinese Quaternary paleodata were also synthesised in Winkler and Wang (1993). Here we shall only discuss the consequences of the last two extreme global scenarios (the coldest and the warmest) on the diverse regions of China.

The principal paleoenvironmental features are represented: coastline, mountain glaciers, permafrost, aeolian formations, surface water, vegetation and climate. It is evident that such documents may only be a rough estimate of paleo-situations as inferred from literature : the purpose of this work is therefore to give a preliminary view of what is presently known of environmental changes in China during two key-periods.

\section{Present-day environments in China}

China has a total land area of 9.6 million $\mathrm{km}^{2}$ and measures some $5,500 \mathrm{~km}$ from north to south. The Chinese mainland is flanked southwards by the Bohai, the Huanghai (Yellow Sea), the East China Sea and the South China Sea. The coastline of the mainland is about $18,000 \mathrm{~km}$ long. Since the Yellow and Yangze Rivers run into the west Pacific, forming deltas and coastal plains in the northern part of China, the geomorphology of the coastline divides into two sections : muddy coasts with wetland and lagoons to the north of the Hangzhou Bay $\left(30^{\circ} 15^{\prime} \mathrm{N}\right)$, and estuaries and sandy coasts with hills and mountains to its south (Figure 1). It is obvious that the northern section of the coastline is more sensitive to sea level changes than the southern one. Another important feature is the wide extent of the continental shelf along the eastern coast of China, which stretches out from the coastline over $500 \mathrm{~km}$.

The present snow-line is the highest in the Tibetan Plateau where it is located between 5,200 $\mathrm{m}$ and 6,200 $\mathrm{m}$ (Wang, 1984; Shi, 1991). However, it lowers both northwards and eastwards. For example, it lies between $3,700 \mathrm{~m}$ and 4,200 $\mathrm{m}$ in Xinjiang region and only at 2,800-3,350 $\mathrm{m}$ in the Altay Mountains (Table 1). Modern glaciers on the mountains of western China cover a total area of $58,651 \mathrm{~km}^{2}$, about half of the mountain glaciers in Central Asia (Huang, 1991). The most expansive glaciers are in the Kunlun and Himalayas mountain ranges (Table 1). The glaciers in China can be geomorphologically classified into valley, cirque and hanging glaciers. The observations on glacial termini from the 60 s to the $70 \mathrm{~s}$ showed that $55 \%$ of them were retreating, while only $26 \%$ were advancing (Shi, 1984). More recent works in the Tianshan, Altay and Pamir show that about $95 \%$ of the glaciers had a negative mass balance over the past 30 years (Dyurgerov, 1994).

Continuous permafrost covers $2,150,000 \mathrm{~km}^{2}$, i.e. nearly $22 \%$ of the Chinese territory. High latitude permafrost, located from $51^{\circ} \mathrm{N}$ northwards, is mostly found on the Daxinganling and Xiaoxinganling mountains of northeastern China (Wang, 1984). In the north of theTibetan Plateau, the lowest limit of permafrost is at about 4,200 m (Wang and French, 1995).

Sand and gravel deserts are the major landforms in northwestern China. The total area covered by "gobi-deserts" is about $1,282,000 \mathrm{~km}^{2}$, extending from $75^{\circ} \mathrm{E}$ to $135^{\circ} \mathrm{E}$ and from $35^{\circ} \mathrm{N}$ to $50^{\circ} \mathrm{N}$, accounting for $14 \%$ of the total Chinese territory (Zhu, 1980). Among the largest deserts are the Taklimakan, Gurbantunggut, Badain Jaran, Tengger, Ulan Buh and Mu Us. About $8 \%$ of the 
Table 1 Snow-line and glaciers in western China (after Huang, 1991).

\begin{tabular}{lccc}
\hline $\begin{array}{l}\text { Mountain } \\
\text { range }\end{array}$ & $\begin{array}{c}\text { Snow-line } \\
(\mathrm{m})\end{array}$ & $\begin{array}{c}\text { Number of } \\
\text { glaciers }\end{array}$ & $\begin{array}{c}\text { Glacier area } \\
\left(\mathrm{km}^{2}\right)\end{array}$ \\
\hline Altay & $2,800-3,350$ & 416 & 293.20 \\
Tianshan & $3,600-4,300$ & 8,908 & $9,196.98$ \\
Qilian Shan & $4,400-5,250$ & 2,856 & $1,973.50$ \\
Pamir & $4,200-5,900$ & 2,112 & $2,993.85$ \\
Kunlun Mts. & $4,500-6,000$ & 1,848 & $12,482.17$ \\
Karakorum & $5,000-5,600$ & 7,774 & $2,642.20$ \\
Qingtang Plateau & $5,600-6,200$ & 1,821 & $3,108.81$ \\
Gangdise & $5,800-6,000$ & 936 & $1,668.00$ \\
Nyainqentanglha & $4,600-5,600$ & 3,099 & $7,536.75$ \\
Tanggula & $5,400-5,700$ & 2,966 & $2,082.00$ \\
Himalayas & $4,300-6,200$ & & $11,055.00$ \\
Hengduan Mts. & $4,600-5,500$ & 1,680 & $1,618.62$ \\
\hline
\end{tabular}

desertified land were formed during historical times. Mu Us desert, for example, was a vast grassland in historical times, and a city was built there in $413 \mathrm{AD}$. Wind-blown sand began to invade its suburbs by $828 \mathrm{AD}$ and the city was eventually destroyed by aeolian deposition in 994 AD (Dong, et al., 1984; IGPD, 1980). Desertification is also well recorded in the Kolsin area, Inner Mongolia, where tall trees and luxuriant grasses were present until the mid-10th century. Nowadays, about $10 \%$ of its surface are covered with shifting sand (Hou,et al., 1982).

Loess is also a kind of remarkable landform in North-central China. The primary sources of loess are wind-born dust from desert areas. The Chinese loess plateau lies today between $30^{\circ} \mathrm{N}$ and $40^{\circ} \mathrm{N}$ and covers an area of about $300,000 \mathrm{~km}^{2}$ with a thickness varying from 100 to $200 \mathrm{~m}$ (Liu, 1991). The thickest loess deposits are found in the western part of the Loess Plateau. The loess in Gansu and Shanxi Provinces covers the entire land surface and three types of landforms can be distinguished: the Yuan (high plain), the Liang (flat-topped range) and the Mao (dome-like hillock) (Wang, 1984; Liu, 1985).

There are about 50,000 rivers in China with a drainage area of more than $100 \mathrm{~km}^{2}$. The Yangtze River, for example, covers a drainage surface of 1.8 million $\mathrm{km}^{2}$, with a length of $6,300 \mathrm{~km}$ (Liu, 1984). Natural lakes are also common, and most of them are scattered in the middle-lower Yangtze River plains and on the Qinghai-Tibet Plateau. About $61 \%$ of the glaciers are located in regions of inland drainage, which results into numerous large and shallow lakes and closed basins surrounding the arid deserts in northwestern China (Huang, 1991). The total area of the marshlands covers 110 million hectares, and most of them are distributed in northeastern China and in the western part of the Sichuan Province. The rivers in the plains of northeastern China, for example, are bordered with wide paludal areas.

The most outstanding climatic features in China are the strong influence of the summer monsoon in the East, the arid and hyperarid conditions in the Northwest and the frozen environment on the Tibetan Plateau (Table 2). The Tibetan Plateau, appearing as a continent in an atmospheric ocean, imposes both dynamic and thermal effects on the climate, and influences the vegetal cover.

The SE monsoon circulation is driven by differential heating between the West Pacific Ocean and the Eurasian supercontinent. It is closely related with the precipitation repartition in China. Therefore, the climate
Table 2 Main climatic characteristics in China.

\begin{tabular}{|c|c|c|c|c|c|}
\hline \multicolumn{2}{|c|}{ Regions } & $\begin{array}{l}\text { Mean annual } \\
\text { temperature } \\
\left({ }^{\circ} \mathrm{C}\right)\end{array}$ & $\begin{array}{l}\text { Annual } \\
\text { precipitation } \\
(\mathrm{mm})\end{array}$ & $\begin{array}{r}\text { Domina } \\
-\quad \text { direc } \\
\text { summer }\end{array}$ & $\begin{array}{l}\text { t wind } \\
\text { ion } \\
\text { winter }\end{array}$ \\
\hline \multirow{4}{*}{$\begin{array}{l}\text { Eastern } \\
\text { monsoon } \\
\text { region }\end{array}$} & $\begin{array}{l}\text { Northeastern } \\
\text { China }\end{array}$ & $-5-7.7$ & $500-800$ & $\mathrm{~S}$ & $\mathrm{~N}-\mathrm{NW}$ \\
\hline & Northern & $12.2-15.7$ & $400-800$ & $\mathrm{~S}$ & $\mathrm{NW}$ \\
\hline & China & & & & \\
\hline & $\begin{array}{l}\text { Southern } \\
\text { China }\end{array}$ & $16.3-23$ & $1,000-2,500$ & S-SE & NW \\
\hline \multicolumn{2}{|c|}{$\begin{array}{l}\text { Northwestern arid } \\
\text { region }\end{array}$} & $4-10$ & $15-300$ & NW-N & S-SW \\
\hline \multicolumn{2}{|c|}{ Tibetan Plateau } & $-4-11$ & $50-600$ & W & W \\
\hline
\end{tabular}

in the East is humid or subhumid, with forest as the dominant vegetation (except for the strong human impact regions). The vegetation in the eastern monsoon zone of China belongs to temperate and subtropical zones. The natural forest formations, from north to south, are mainly cold conifer forest, conifer and deciduous mixed forest, deciduous broad-leaved forest, mixed broad-leaved forest, evergreen broad-leaved forest, evergreen monsoon forest and rain forest (Wu, et al., 1980).

The arid areas in northwestern China belong to the eastern section of the immense Eurasian deserts and steppes (Wang, 1981). However, some conifer (Picea) forests can be found in the Altay and Tianshan Mountains. As for the Tibetan Plateau, there is an increasing desiccation tendency from the southeast to the northwest, in close relation with the mountain block of moisture-bearing air masses, coming from the Indian Ocean and the Pacific. The vegetation there, is well forested on the south and southeastern slopes, but steppic on the high plateau and desertic in the Kunlun Mountains (Cui, 1988).

\section{The Last Glacial Maximum}

During the Last Glacial Maximum, sea level was 120 to $130 \mathrm{~m}$ lower than today, and the coastline of the East China had shifted by 600$1,000 \mathrm{~km}$ eastwards from its present location (Wang and Wang, 1980; An, et al., 1991). The Korean Peninsula, Taiwan and Hainan

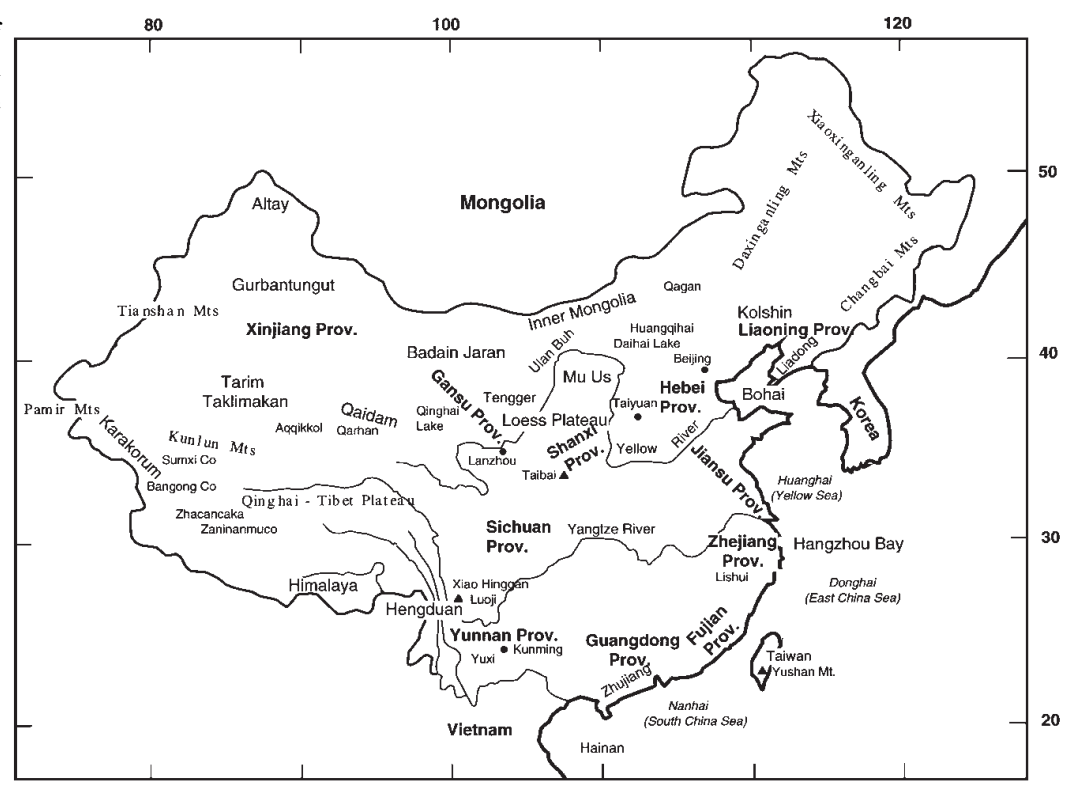

Figure 1 Location of places quoted in the text. 
Islands were connected to the mainland, resulting into the disappearance of Bohai and Huanghai (Yellow Sea). The South China Sea was much smaller and almost closed (Wang et al., 1995). The increased continentality then reinforced the drier and colder climate over the Chinese mainland.

According to the paleodata and the radiocarbon ages, it can be assertained that the LGM snowline was lowered by $300-1,000 \mathrm{~m}$ on the mountains of western China. The snow-line depression was rela-

Table 3 Lowering of the permafrost limit in China during the Last Glacial Maximum (after Zhou, et al., 1991).

\begin{tabular}{lrrr}
\hline $\begin{array}{l}\text { Mountain } \\
\text { range }\end{array}$ & Latitude & $\begin{array}{c}\text { Present-day } \\
\text { permafrost limit } \\
\text { (altitude) }\end{array}$ & $\begin{array}{c}\text { LGM permafrost } \\
\text { limit } \\
\text { (altitude) }\end{array}$ \\
\hline Altay & $47-49^{\circ} \mathrm{N}$ & $2,200-2,800 \mathrm{~m}$ & $1,000-1,600 \mathrm{~m}$ \\
Tianshan & $44-45^{\circ} \mathrm{N}$ & $2,700-3,100 \mathrm{~m}$ & $1,900-2,300 \mathrm{~m}$ \\
Qilian & $37-40^{\circ} \mathrm{N}$ & $3,500-3,900 \mathrm{~m}$ & $2,700-3,100 \mathrm{~m}$ \\
West Kulun & $36^{\circ} \mathrm{N}$ & $4,400-4,500 \mathrm{~m}$ & $3,900-4,000 \mathrm{~m}$ \\
Central Kunlun & $35^{\circ} \mathrm{N}$ & $4,150-4,200 \mathrm{~m}$ & $3,600-3,700 \mathrm{~m}$ \\
East Kunlun & $34.5^{\circ} \mathrm{N}$ & $3,700-3,800 \mathrm{~m}$ & $3,200-3,300 \mathrm{~m}$ \\
Tangula & $32.5^{\circ} \mathrm{N}$ & $4,600-4,650 \mathrm{~m}$ & $4,100-4,200 \mathrm{~m}$ \\
Gongga & $29.5^{\circ} \mathrm{N}$ & $4,600-4,900 \mathrm{~m}$ & $3,600-3,900 \mathrm{~m}$ \\
Himalayas & $28^{\circ} \mathrm{N}$ & $5,100-5,300 \mathrm{~m}$ & $4,800-5,000 \mathrm{~m}$ \\
Wutai & $38^{\circ} \mathrm{N}$ & $2,300 \mathrm{~m}$ & $1,800 \mathrm{~m}$ \\
Taibai & $34^{\circ} \mathrm{N}$ & $3,000 \mathrm{~m}$ & $2,500 \mathrm{~m}$ \\
Changbai & $42^{\circ} \mathrm{N}$ & $1,800 \mathrm{~m}$ & $800 \mathrm{~m}$ \\
\hline
\end{tabular}

tively moderate in the inner regions of the Tibetan Plateau and of the western Kunlun mountains (300-500 m lower), whereas it was much greater on the southeastern flanks of the high plateau, particularly on the southern slopes of the Himalayas, reaching 1,000 m or even more (Shi, 1991). There is no doubt that glaciers widely expanded during the LGM in western China and, to a less extent, in eastern China, such as in the Taibai Mts ( $\left.3767 \mathrm{~m}, 33^{\circ} 55^{\prime} \mathrm{N}, 102^{\circ} 21^{\prime} \mathrm{E}\right)$, Luoji Mts (4359 $\left.\mathrm{m}, 27^{\circ} \mathrm{N}, 102^{\circ} 21^{\prime} \mathrm{E}\right)$, Xiao Hinggan $\left(4045 \mathrm{~m}, 28^{\circ} 4^{\prime} \mathrm{N}, 102^{\circ} \mathrm{E}\right)$ and Changbai Mts $\left(2749 \mathrm{~m}, 42^{\circ} \mathrm{N}, 128^{\circ} \mathrm{E}\right)$, and even like the Yushan Mts in Taiwan Island $\left(3950 \mathrm{~m}, 23^{\circ} 30^{\prime} \mathrm{N}, 121^{\circ} \mathrm{E}\right)$. However, it is now generally agreed that an inlandeis cover on the Tibetan Plateau did not exist during this glacial phase. Furthermore, a study of the glacial history of the central Himalayas shows that the glacial maximum there (ca 63,000 yr BP) does not coincide with the LGM of the northern hemisphere ice sheet (Sharma and Owen, 1996). Recently, several ice cores drilled on the Qinghai-Tibetan Plateau have been studied (Thompson et al., 1989; 1997). The relatively high anion and microparticles at the LGM from the Dunde ice core primarily reflect the dust influx from the Taklimakan and Qaidam deserts. Recent results also show that the $\delta^{18} \mathrm{O}$ values decrease to their lowest levels during the LGM, which is consistent with the patterns in polar records (Thompson et al, 1997).

The permafrost limit in northeastern China evidently moved southwards during the LGM. Its southern limit extended from the southern Liaoning Province to the regions around $41-42^{\circ} \mathrm{N}$, i.e. Liaodong Peninsula, Beijing, Taiyuan, Lanzhou and Hengduan Mts (Guo and $\mathrm{Li}, 1981$ ). This assumption is supported by paleo-permafrost relics, including pingoscars, sand wedges, ice-wedge casts and polygonal soils or folded layers (Zhou, et al., 1991). The LGM permafrost southern limit matches the present temperature isotherm of 7-8 ${ }^{\circ} \mathrm{C}$, suggesting a $c 8{ }^{\circ} \mathrm{C}$ cooling in these areas. Table 3 indicates the lowest permafrost limit in the mountains, at present and during the LGM, evaluated from relic records and taking the snowline depression into account.

Due to the strong winter monsoon, the desert areas in northwestern China were more extensive than at present, with the limits of active sand dunes shifting eastwards and southwards. The sand dunes even invaded the steppe and sandy regions like $\mathrm{Mu}$ Us and Kolshin, as well as the lower ground of the Yellow and Yangtze rivers. The loess deposition became much wider, covering the middle and lower reaches of the Yangtze River and the mountain slopes to the west of the Sichuan basin. On the Chinese Loess Plateau, the loess deposited, during the LGM changes, from silty loess to clayey loess in a downwind (southeasterly) direction, as it becomes thinner. The well-developed loess and paleosols provide an excellent longterm climatic proxy record. Since the 1980s, the loess has been an interesting topic of research being one of the most imposing landforms in China which could be very sensitive to the winter monsoon variations during the glacial-interglacial intervals. A number of exposed loess sections in the central loess plateau has thus been studied by Liu (1985; 1991), Liu et al. (1986), Kukla and An (1989) and Porter and An (1995). The techniques used to study the evolution of the paleoenvironment include soil development, magnetic measurements, grain-size analysis, organic carbon content, mollusca shells, rare earth elements, microfabric and micromorphology (Wake and Mayewski, 1996). The loess sequence L1, known as the Malan loess, was deposited during the last glacial cycle under drier and colder conditions, and the substage L1-1 represents the LGM event (Liu, et al., 1986). The loess was deposited during the LGM (10-30 m) at an inferred average rate of $0.35 \mathrm{~mm}$ per year, which confirms the enhancement of dust accumulation (Dawson, 1992). The loess interdisciplinary studies also show that loess dust accumulation is more coherent with the variations of the global ice volume than with those of orbital insolation, suggesting that the aeolian dust deposition is causally related to the development of continental ice sheets (Shackleton et al., 1995, Ding et al., 1996).

The expansion of the loess deposits was coeval with the low level of inland lakes. A Late Pleistocene salt deposition was discovered in many sites such as the Baingoin lake in Tibet (Zheng et al., 1983), the Qarhan lake in the Qaidam basin, the Qagan lake in Inner Mongolia and the Aydingkol lake in Xinjiang (Li, et al., 1989). The study of a salt lake in the Qaidam basin $\left(36-39^{\circ} \mathrm{N}, 91-99^{\circ} \mathrm{E}\right)$ with evidence of halite deposition and clastics identical in chemical composition to the Malan loess (Winkler and Wang, 1993), shows that the lake level was lower and the lake size remarkably reduced. The lakes Qinghai (Tibet) and Daihai (Inner Mongolia) also had low levels. Effectively, the LGM low lake levels were recorded not only in the northwestern regions of China, but also on the Tibetan Plateau (Van Campo and Gasse, 1993) and throughout eastern China, including the tropical regions (Fang, 1991; Zheng and Lei, in press). Many lakes in the middle and lower reaches of the Yangtze River reduced or even disappeared and were replaced by loess-like deposits (Wang and Li, 1991). However, some studies from Yunnan, in southwestern China, show that the lake levels were higher during the LGM in a number of basins like Kunming, Xinjie and Yuxi (NIGL, 1989).

A great number of pollen analysis indicate that both desert and steppe vegetation extended and invaded the eastern part of China during the LGM (Ke and Sun, 1992; Kong and Du, 1980; Kong, et al., 1994). A steppe vegetation in northeastern China is also indicated by the distribution of fossil mammals of Mammuthus primigenius (woolly mammoth) and Coelodonta antiquitatis (woolly rhinoceros) at more than 200 sites in the region (Qiu et al., 1981). The northern cold climate animals like Cricetulus, Microtus brandti and Ursus arctos spreaded to Yuhang in the Zhejiang Province and to Lishui in the Jiangsu Province, regions located to the south of the Yangtze River (Zheng and Han, 1991). In the temperate zone of eastern China, vegetation boundaries shifted deeply southwards. The boreal conifer (mainly Picea, Abies, Larix and Betula) forests replaced the temperate deciduous forest in a large part of eastern China (Winkler and Wang, 1993), and the tropical rain forest moved out of China (Zheng, 1991). Numerous researches focused on the Tibetan plateau demonstrate that a desert-steppe vegetation (mainly with Chenopodiaceae and Ephedra in the northwest, and Artemisia and Cyperaceae in the center and southeast) covered the greatest part of the Tibetan plateau (Tang and Shen, 1996; Van Campo and Gasse, 
1993), and that the forest formation only existed in the extreme south and east of the plateau (Tang, 1996). The tree line was about 1,200 $m$ lower than nowadays.

According to the paleoclimatic proxy data, the greater part of China was drier and colder. The annual mean temperature in northern and central China was at least $7{ }^{\circ} \mathrm{C}$ to $10{ }^{\circ} \mathrm{C}$ lower than today, as inferred from both pollen and permafrost limits (Zhou, et al., 1991; Sun and Chen, 1991), although some estimates were larger (10-12 ${ }^{\circ} \mathrm{C}$ lower) (Cui and Xie, 1985; An, et al., 1991). The lowering of the mean annual temperature in eastern Tibet was estimated to be $4.8^{\circ} \mathrm{C}$ to $7.9^{\circ} \mathrm{C}$, but $6{ }^{\circ} \mathrm{C}$ for January in southeastern Tibet, where a $250 \mathrm{~mm}$ annual rainfall was inferred (Shen, et al., 1996). Similarly, in southern subtropical China, it was about $4 \mathrm{C}^{\circ}$ to $6{ }^{\circ} \mathrm{C}$ lower when mountain forest boundaries lowered (Zheng and Lei, in press). The annual precipitation in the north was 200 to $300 \mathrm{~mm}$ lower than at present (Kong and $\mathrm{Du}, 1981$ ), and 400 to $600 \mathrm{~mm}$ lower in the regions presently under the monsoon influence.

Many records have proved that paleomonsoons varied at a large scale during the LGM (Yan and Petit-Maire, 1994). The loess sequence is one of the well-studied records containing paleomonsoon signals (An et al., 1991b). For instance, magnetic susceptibility and particle-size measurements of some soil samples from diverse localities of the Chinese loess plateau were used as indicators of variations in intensity of the East Asian winter monsoon (Ding et al., 1995). These works showed a clear increase in coarse-size loess grains that accumulated during the LGM, suggesting that the enhanced southeastern movements of cold polar frontal air produced a predominant spatial sorting of loess grains during a subaerial transport (Liu et al., 1989; Zhang, 1984). The strengthening of the winter monsoon is also obvious in eastern China and even in central Japan, where the aeolian quartz flux in lake deposits markedly increased at the LGM (Xiao et al., 1997). Some results also indicate that a stronger East Asian winter monsoon was coupled with cooler and drier conditions, in response to the increased continentality of the Chinese mainland, to sea level depression and to lower SSTs (Winkler and Wang, 1993; Wang and Wang, 1990; Zheng and Lei, in press).

\section{The Holocene Optimum}

The marine transgression rapidly flooded the continent since 11,000 yr BP, and reached its maximum at about 6,000-7,000 yr BP (Wang and Wang, 1980). Many deltaic sediment records, like coastal lacustrine and salt marshes, tidal flats and shelf deposits testify to strong marine and deltaic influences at the Holocene optimum, the absolute rise reaching about 2 to $3 \mathrm{~m}$ above the present-day sea level (Yang, 1991). The Holocene transgressive process deeply modified the coastline landscape to the north of Hangzhou Bay. The studies on Yangtze River deposits show that the transgression could affect areas upstream as far as 1,600 km from the present-day river mouth (Yang, 1991). Along the western coast of the Bohai Sea and of theYellow Sea, complex deltaic deposits of the Yellow River were accumulated since the deglaciation and during the transgression: they cover nowadays a huge area of about $29,400 \mathrm{~km}^{2}$ in northern China. This resulted into the displacement of the Yellow and Luanhe river mouths by $600 \mathrm{~km}$ at the most (Xue, et al., 1991). Therefore, it is evident that the changes of coastal environments were mainly controlled by a sea level rise prior to $6,000 \mathrm{yr} \mathrm{BP}$, and by a delta progradation after 6,000 yr BP (Xue et al., 1995). In contrast, the coastline to the south of Hangzhou Bay was relatively stable during the Holocene optimum. The Zhujiang river (Pearl river) mouth became an estuary at 6,000-7,000 $\mathrm{yr} \mathrm{BP}$ and, since then, was filled up with deltaic sediments (Xue, et al., 1991).

The glaciers in western China rapidly retreated, while those in eastern China completely disappeared, due to the warmer climate since the early Holocene. Three glacial fluctuation stages can be distinguished during the Holocene: a slow retreat at 10,000-8,000 yr $\mathrm{BP}$, a rapid retreat at $8,000-3,000 \mathrm{yr} \mathrm{BP}$, and alternating advances and retreats from 3,000 BP on (Zheng and Shi, 1982). The warming also resulted in the degradation of permafrost and the northern shift of its boundary. However, permafrost could still be observed on the Tibetan plateau and in other regions of high altitude (Wang, et al., 1979). In northeastern China, the permafrost southern limit was located about $100 \mathrm{~km}$ to the north of its current situation. Studies of the Guliya ice core from Tibet show high $\delta^{18} \mathrm{O}$ and $\mathrm{CH}_{4}$ values throughout the Holocene, particularly in the early Holocene, which is correlative with warmer, moister conditions in the subtropics and argues strongly for a low-latitude methane source at that time (Thompson et al, 1997).

The desert and loess distributions were clearly reduced during most of the Holocene. A series of sections on the Chinese loess plateau indicate that the loess deposition rate lowered at the very beginning of the Holocene, and that the soils rapidly developed during the Holocene optimum, due to the less intensive winter monsoon circulation (Liu, 1985). In the sandy areas of Mu Us and Kolshin, dunes vegetated and consolidated and oasis were well developed during the Holocene megathermal (Gao et al., 1992).

Most lakes levels in China were high during the Holocene optimum. The highest levels in the northern and central regions were between 6,000 and 3,000 yr BP, and between 9,000 and 7,000 yr BP (Fang, 1991), therefore possibly recording a drier episode between 7000 and $6000 \mathrm{BP}$, as already observed by Petit-Maire and Guo (1996). In northeastern China and on the Tibetan plateau, many basins received ice-melt water to form larger lakes. The layers of freshwater mud found in Lake Zhacancaka $\left(32^{\circ} 30^{\prime} \mathrm{N}, 82^{\circ} 20^{\prime} \mathrm{E}\right)$ indicate several millennial-scale wet periods, between 8000 and $5000 \mathrm{yr}$ BP (Wang and Fan, 1987). Three Holocene lake terraces were also found above the present level of Lake Zharinanmuco $\left(31^{\circ} \mathrm{N}, 85^{\circ} \mathrm{E}\right)$ (Li et al., 1985; Winkler and Wang, 1993). Several lakes in western Tibet (Sumxi Co and Bangong Co) also reveal that lake levels were higher with warmer and wetter conditions during the Holocene megathermal (Gasse et al, 1991; 1996). The lake level records from Qinghai closed-basin show that the maximum level was at about 8,000 yr BP (Lister et al., 1991). Lakes Daihai and Huangqihai, in Inner Mongolia, show their highest levels between 8,500 and 6,000 yr BP with a warmer and wetter climate (Li et al., 1992).

A great number of palynological studies on the Holocene vegetation changes in China have been carried out since the 80s. In eastern China, a boreal conifer forest is believed to have moved north of the 50th parallel, i.e. about $200 \mathrm{~km}$ further north than nowadays. Temperate mixed and deciduous forests covered a large part of northern and northeastern China, i.e. about $5^{\circ}$ further north than nowadays. Some sites from Hebei plain demonstrate an increase in deciduous broad-leaved forest elements between 9,000 and 2,000 yr BP (Yan, et al., 1981). The present-day steppe areas in Inner Mongolia were covered with a forest or forest-steppe vegetation ( $\mathrm{Li}$ et al, 1992). The subtropical monsoon evergreen broad-leaved forest extended to the domain of the Yangtze River, at $35^{\circ}-37^{\circ} \mathrm{N}$ (Sun and Chen, 1991). When sea level was higher at the Holocene megathermal, the tropical mangrove forest was very developed in the littoral areas of Fujian and Guangdong Provinces (Zheng, 1995). As for western China, a rise of arboreal pollen (mainly sub-alpine conifers) was observed in the Qinghai lake for the interval dated 8,000 to $3,500 \mathrm{yr}$ BP (Du et al., 1989). On the central Tibetan plateau, a montane and alpine steppe with Cyperaceae, Artemisia and Gramineae, with some tree elements, widely developed between 9,600 and 6,000 yr BP. The Artemisia steppe or sub-desert occupied western Tibet, inferring wetter conditions and higher precipitation in comparison with the arid climate at the LGM (Tang and Shen, 1996). The continental fauna also demonstrates an optimal climate for the subtropical or Indo-malayan species such as Hyaena, Acinonyx, Rhinoceros, Elephas and Pongo (Zheng and Han, 1991). Elephas maximus, Rhinoceros sandaicus and Tapicus indicus lived as far north as $34^{\circ}-41^{\circ} \mathrm{N}$

Temperature estimates for the Holocene optimum were $1{ }^{\circ} \mathrm{C}$ to $6{ }^{\circ} \mathrm{C}$ higher than today, depending on the geographical location. The general temperature relative to nowadays was, from roughly 8,500 to 5,000 yr BP, $+2{ }^{\circ} \mathrm{C}$ to $+4{ }^{\circ} \mathrm{C}$ after An et al. (1991), and +3 to $+5{ }^{\circ} \mathrm{C}$ 
after Zhang et al. (1997). Sun and Chen (1991) summarised that it might be $4{ }^{\circ} \mathrm{C}$ to $6{ }^{\circ} \mathrm{C}$ higher in some areas of Tibet, $3{ }^{\circ} \mathrm{C}$ to $4{ }^{\circ} \mathrm{C}$ in northern China, $2{ }^{\circ} \mathrm{C}$ to $4{ }^{\circ} \mathrm{C}$ in eastern China (Xu, 1989) and only 1 to $2{ }^{\circ} \mathrm{C}$ in southern China (Walker, 1986). A similar synthesis was also made by Shi et al. (1992), suggesting that the average annual temperature was about $4{ }^{\circ} \mathrm{C}-5{ }^{\circ} \mathrm{C}$, i. e. $3^{\circ} \mathrm{C}, 2^{\circ} \mathrm{C}$ and $1^{\circ} \mathrm{C}$ higher than today, respectively, on the Qinghai-Tibet Plateau cold temerate areas, warm temperate areas and subtropical areas. A recent study, using the pollen analogue concept to reconstruct paleoclimate, shows a synchronous change of positive anomalies in the whole of eastern China at 7,000-6,000 yr BP (Yu and Qin, 1997), the calibrated annual temperature being then $3.1,1.8,2.2$ and $3.6^{\circ} \mathrm{C}$ higher than today in the Northeast, the North, the Centre and the South of China respectively. If the above temperature estimates are exact, northern China should be one of the warmest regions in the northern hemisphere during the Holocene Optimum, if compared with the results calibrated by Velichko et al. (1991). The warmer climate in China and the higher SSTs in the Pacific and Indian Oceans strengthened the summer monsoon circulation, with more abundant, but contrasted seasonal precipitation (Yan and Petit-Maire, 1994). The annual rainfall in the southeastern monsoon areas was at least 100 $\mathrm{mm}$ higher than at present (An et al., 1991), and could reach $400 \mathrm{~mm}$ in some regions. The quantitative estimates in annual precipitation for the mid-Holocene, based on 113 pollen sites, were consistently greater than today (50-300 mm/yr) throughout eastern China (Yu and Qin, 1997). On the Tibetan plateau, the southwestern monsoon began to increase at 11,000 yr BP, and reached its maximum at around 7,000 yr BP (Tang and Shen, 1996). The pollen ratio of Artemisia/Chenopodiaceae, a moisture indicator, was the highest between 7,700 and 4,300 yr BP in western Tibet (Van Campo, et al., 1993).

\section{The future}

A global climatic change is most probably current, due to the rapid increase of radiative gases $\left(\mathrm{CO}_{2}, \mathrm{CH}_{4}\right.$, and $\left.\mathrm{N}_{2} \mathrm{O}\right)$ in the atmosphere. In addition, chlorofluorocarbons (CFCs), which have heat-holding capacities 15,000 times greater than $\mathrm{CO}_{2}$, are also being added by man to the troposphere. The enhancing of the natural greenhouse effect by this pollution should, according to models, induce a global warming of $+1{ }^{\circ} \mathrm{C}$ to $+3{ }^{\circ} \mathrm{C}$ in the 21 st century. As has been proposed for the Sahara desert (Petit-Maire et al., 1990), one can assume that the effect of this man-made rise of global temperature will probably be of the same nature (even if not of the same degree) as past climate warmings, despite the fact that its causes are different and not an analogue by all means. An activation of the monsoons would be the first consequence of any warming events (Petit-Maire, 1990). The climatic and environmental future would then develop towards a scenario related to the one observed for the Holocene optimum, which corresponds to a global warming of about $2{ }^{\circ} \mathrm{C}$ and to Chinese estimates of $+2 \mathrm{C}^{\circ}$ to $+4^{\circ} \mathrm{C}$ relative to nowadays. The future climatic changes will certainly be much more abrupt and extended than in the early Holocene, since the last step of deglaciation and the effects of orbital forcing upon the earth continental environments were generally quite slow at human scale, while very rapid at geological time. The following oncoming problems should lead us to pay attention:

1. Abrupt climatic changes induce a rupture of the present-day stable situation and bring out, before a new stability is reached, severe natural hazards such as extra-tropical cyclones, floods, droughts, land-slides, etc. Such events were already observed at least one decade ago (Flohn, 1987, 1989).

2. During the early Holocene, human population was scarce and, except in coastal areas and river plains, little concerned with slow climatic change. Instead, the highly populated modern China is liable to be severely affected by the rapid oncoming environmental changes, particularly in the flat deltaic regions like the northern coastal areas of China where even a moderate sea-level rise (estimated to some $0,5 \mathrm{~m}$ in 2050) would have severe effects.
3. Moreover, it is difficult to transpose past natural changes of natural landscapes into future man-made changes of man-made landscapes, as is the case in China.

\section{Acknowledgements}

This research was supported by the Programme de Recherches Avancées de Coopération Franco-Chinoise (PRA E-95-04) of the Association Franco-Chinoise pour la Recherche Scientifique et Technique, and by the Chinese Natural Science Foundation. We thank Zheng-Tang Guo for his important bibliographical contribution.

\section{References}

An, Z. S., Wu, X. H., Lu, Y. C., Zhang, D. E., Sun X. J., Dong, G. R., and Wang S. M., 1991, Paleoenvironmental changes of China during the last 18,000 yaers. in T.S. Liu ed., Quaternary geology and environment in China: Science Press, Beijing, pp. 214-227.

An, Z. S., Wu, X. H., Wang, P. X., Wang, S. M., Dong, G. R., Sun, X. J., Zhang, D. E., Lu, Y. C., Zheng, S. H. and Zhao, S. L., 1991b, Paleomonsoons of China over the last 130,000 years: Science in China (Series B) no. 34 , pp. 1007-1024.

Cui, H., 1988, Vegetation types on northern slopes and the interior of Central Kunlun: Acta Phytoecologica et Geobotanica Sinica, v.12, pp. 91-103 (in Chinese).

Cui, Z. J. and Xie, Y. Y., 1985, On late Pleistocene periglacial environments in the northern part of China. in T.S. Liu ed., Quaternary geology and environment in China, Beijing, China Ocean Press (in Chinese), pp. 226-232.

Dawson, A. G., 1994, Ice age earth: Late Quaternary geology and climate: Biddles Ltd, Guildford and King's Lynn, London, 293p.

Ding, Z., Liu, T., Rutter, N. W., Yu, Z., Guo, Z. and Zhu, R., 1995, Ice-volume forcing of East Asian winter monsoon variations in the past 800,000 years: Quat. Res., v. 44, pp. 149-159.

Dong, G., Gao, S., Ji, Z., and Li, B., 1984, The problem of formation, development and origin of Mu Us Sha Mo (desert): Scientia Sinica, v. 6, pp. 633-642.

Du, N. Q., Kong, Z. C., and Shan, F. S., 1989, A preliminary investigation on the vegetational and climatic changes since 1,100 years in Qinghai lake an anlaysis based on palynology in core QH875-14C: Acta Botanica Sinica, v. 31, pp .803-814 (in Chinese).

Dyurgerov, M., 1994, Global glacier mass balance monitering Part I: Mass balance fluctuation and their contribution of sea level changes. USA Department of State and Institute of Geography of Rassian Academy of Sciences.

Fang, J. Q., 1991, Lake evolution during the past 30,000 years in China, and its implications for environmental changes: Quat. Res., v. 36, pp. 37-60.

Flohn, H., 1987, Recent climate evolution as a scenario for abrupt paleoclimatic events ? in B. Frenzel, ed. Klimageschichtliche Problem der letzen 130,000 Jahre, Fisher, Stuttgart, pp. 165-176.

Flohn, H., 1989, Climate evolution during the last millenium: What can we learn from it? Global changes in the perpective of the Past, v.19, pp. 296-316.

Gao, S. Y, 1992, The desert of Holocene megathermal in China. In The climates and environments of the Holocene megathermal in China: Beijing, Ocean Press, pp. 161-167

Gasse, F., Anold, M., Fontes, J. C., Gibert, E., Huc, A., Li Bingyuan, Li Yuangfang, Li Qing, Melieres, F., Van Campo, E., Wang Fubao, and Zhang Qingsong, 1991, A 13,000 year climate record from western Tibet: Nature, v. 353, pp. 742-745.

Gasse, F., Fontes, J. C., Van Campo, E., Wei, K., 1996, Holocene environmental changes in Bangong Co basin (West Tibet), Part 4 : A discussion: Palaeogeogr., Palaeoclimat., Palaeoecol., v. 120, pp. 79-92.

Guo Dongxin and Li Zuofu, 1981, Preliminary approach to the history and age of permafrost in Northeast China. Journal of Glaciology \& Geocryology, v. 3, pp. 1-17 (in Chinese).

Hou, R., Zhu, Z., and Liu. S., 1982, The change of deserts in historic periods, Physical geography of China: Historical Physical Geography: Beijing Science Press, (in Chinese)

Huang, M., 1991, The existing glaciers in China. in T.S. Liu ed. Quaternary geology and environment in China: Beijing, Science Press, pp. 28-33. 
IGPD (Institute of Glaciology, Permafrost and Desert of Lanzhou), 1980, General review of the desert of China: Beijing, Science Press, (in Chinese).

Ke, M. H. and Sun, J. Z., 1992, Paleoclimate and paleoenvironment of the last glacial stage in Salawusu area of Inner Mongolia: Acta Botanica Sinica, v. 34, pp. 717-719 (in Chinese).

Kong, Z. C and Du, N. Q., 1980, Vegetation and Climate changes in the past 30,000-10,000 years in Beijing: Acta Botanica Sinica, v. 22, pp. 331-338 (in Chinese).

Kong, Z. C and Du, N. Q., 1981, Sporo-pollen analysis of some archeological sites and preliminary discussion on the past flora and climate of Neimonggu Zhizhiqu: Acta Phytoecologica et Geobotanica Sinica, v.5, pp. 193-202 (in Chinese).

Kong, Z. C., Du, N. Q., Sun, C. Q. \& Zhang, J. H., (1994), Study on the vegetation and natural environment based on pollen analysis in Bailiandon ruins, in G.X. Zhong ed., Proceedings of China-Japan international conference on relationship between palaeoanthropology and prehistoric culture: Beijing, International Broadcast Press of China. (in Chinese), pp. $176-210$

Kukla, G. and An, Z., 1989, Loess stratigraphy in central China: Palaeogeogr. Palaeoclim. Palaeoecol., v. 72, pp .203-225.

Li, B. X., Cai, B. Q., and Liang Q. S., 1989, The sedimentary characters of Aydingkol lake in Turpan Basin: Chinese Science Bull., no. 8, pp. 608-610 (in Chinese).

Li, B. Y., Yang, Y. Z., Zhang, Q. S., and Wang, F. B., 1985, On the environmental evolution of Xizang (Tibet) in Holocene, in T.S. Liu, ed., Quaternary Geology and Environment of China: Beijing, China Ocean Press, and New York, Springer-Verlag, p. 234-240.

Li, H. Z., Liu, Q. S., and Wang, J. X., 1992, Study of evolution of Huangqihai and Daihai lakes in Holocene in Inner Mongolia plateau: Journal of Lake Sciences, v. 4, pp. 31-39 (in Chinese).

Lister, G. S., Kelts, K., Chen, K., Junqing Y., 1991, Lake Qinghai, China: closed-basin lake levels and the oxygen isotope record for Ostracoda since the latest Pleistocene: Paleogeogr. Paleoclim. Paleoecol., v. 84, pp. $141-166$.

Liu, C., 1984,. A brief review of the research on hydrology in China. in Zheng, X. ed., Geography in China: Beijing, Science Press, pp. 51-68.

Liu, J. L., 1992, The Holocene hyperthermal in the west part of Changbai mountain, in The Climate and Environments of the Holocene Megathermal in China: Beijing, Ocean Press, pp. 25-32 (in Chinese).

Liu, T. S., 1985, Loess and the environment: Beijing, China Ocean Press (in Chinese).

Liu, T. S. ed., 1985, Loess and the Environment: Beijing, Science Press, pp. 294-321 (in Chinese)

Liu, T. S., 1991, Loess, Environment and Global Changes: Beijing, Science Press, (in Chinese)

Liu, T. S., Zhang, S., and Han, J., 1986, Stractigraphy and paleoenvironmental changes in the loess of central China: Quat. Sci. Rev., v. 5, pp 489-495.

Liu, T. S., Ding, Z. L., Chen, M. Y., and An, Z. S., 1989, The global surface energy system and the geological role of wind stress: Quaternary International, v. 2, pp .43-54

NIGL (Nanjing Institute of Geography and Limnology, Chinese Academy of Sciences, 1989, Environments and sedimentation of fault-lake, Yunnan Province: Beijing, Science Press (in Chinese).

Petit-Maire, N., 1990, Will greenhouse green the Sahara? Episodes, v. 13, no.2, pp. 103-107.

Petit-Maire, N., Guo Zhengtang, 1996, Mise en évidence de variations climatiques holocènes rapides, an phase dans les déserts actuels de Chine et du bord de l'Afrique, C. R. acad. SC. Paris: 322, v. 10, pp. 847-851.

Porter, S. C.and An, Z., 1995, Correlation between climate events in the North Atlantic and China during the last glaciation: Nature, v. 375: pp. 305-308.

Qiu, S. W., Jiang, P., Li, F. H., Xia, Y. M., Wang, M. H., and Wang, P. F., 1981, The study of environmental changes since the last-glacial period in northeastern China: Acta Geographica Sinica, v. 36, pp. 315-327.

Shackleton, N. J., An, Z. S., Dodonove, A. E., Gavin, J., Kukla, G. J., Ranov, V. A., and Zhou, L. P., 1995, Accumulation rate of loess in Tjikistan and China: Relationship with global ice volume cycles: Quaternary Proceedings, no. 4, Quaternary Research Association, Cambridge, U.K., pp. $1-14$.

Sharma, M. C. and Owen, L. A., 1996, Quaternary glacial history of NW Garhwal, Central Himalayas: Quat. Sci. Rev., vol.15 : pp. 335-365.

Shen, C. M., Tang, L. Y. and Wang, S. M., 1996, Vegetation and climate during the last 22,000 years in Zoige region: Acta Micropalaeontologica Sinica, v. 13, pp. 401-406 (in Chinese)
Shi, Y., 1984, Progress in the study of glaciology, cryopedology and mountain hazards in China, in Zheng, X., ed., Geography in China: Beijing, Science Press, pp. 69-78.

Shi, Y., 1991, Glaciers and glacial geomorphology in China, in Liu T. S. ed., Quaternary geology and environment in China: Beijing, Science Press, pp. 16-27.

Shi, Y., Kong, Z., Wang, S., Tang, L., Wang, F., Yao, T., Zhao, X., Zhang, P., Shi, S., 1992, Basic feature of climates and environments during the Holocene Megathermal in China In The Climate and Environments of the Holocene Megathermal in China: Beijing, Ocean Press, pp.1-18 (in Chinese).

Sun, X. and Chen, Y., 1991, Palynological records of the last 11,000 yr in China: Quat. Sci. Rev., v. 10, pp. 537-545.

Tang, L. Y. and Shen C. M., 1996, Late Cenozoic vegetational history and climatic characyteristics of Qinghai-Xizang Plateau: Acta Micropalaeontologica Sinica, v. 13, pp. 321-338 (in Chinese).

Thompson, L. G., Mosley-Thompson, David, M. E., Bolzan, J. F., Dai, J., Yao, T., Gundestrup, N., Wu, X., Klein, L., and Xie, Z., 1989, HoloceneLate Pleistocene climate ice core records from Qinghai-Tibetan Plateau: Science, v. 246, pp. 474-477.

Thompson, L. G., Yao, T., David, M. E., Henderson, K. A., Mosley-Thompson, E., Lin, P. N., Beer, J., Synal, H. A., Cole-Dai, J. and Bolzan, J. F., 1997, Tropical climate instability: the last glacial cycle from a QinghaiTibetan ice core: Science, no.276, pp. 1821-1836.

Van Campo, E. and Gasse F., 1993, Pollen and diatom-infered climatic and hydrological changes in Sumxi Co Basin (west Tibet) since 13,000 yr BP. Quat. Res., v. 39, pp. 300-313.

Velichko, A. A., Klimanov, V. A., Borzenkova, I. I., 1991, Climate between 6000 and $5500 \mathrm{yr}$ BP., in Velichko A. A., Frenzel B. and Pecsi M., eds., Explanatory Note of the Atlas of Paleoclimates and Paleoenvironments of the northern hemisphere: Budapest, Geography Institute, Hungariuan Academy of Science, pp. 131-132.

Wake, C. P. and Mayewski, P. A. (eds.), 1996, Himalayan interdiciplinary paleoclimate project-science and implementation plan: PAGES Workshop Report, Series 96-1, pp. 1-96.

Walker, D., 1986, Late Pleistocene-Early Holocene vegetational and climatic changes in Yunnan Province, Southwest China: Journal of Biogeography, v. 13 , pp. $477-486$

Wang, B. and French H., 1995, Permafrost on the Tibet Plateau, China: Quat. Sci. Rev., v. 14, pp. 255-274.

Wang, F. B., 1992, Elementary features of Holocene climate and environment on the Qinghai-Xizang plateau. in The Climate and Environments of the Holocene Megathermal in China, Beijing, Ocean Press, pp. 197-205 (in Chinese).

Wang, F. B. and Fan, C. Y., 1987, Climatic changes in Qinhai-Xizang (Tibet) region of China during the Holocene: Quat. Res., v. 28, pp. 50-60.

Wang, J., Wang, S., and Qiu, G., 1979, Permafrost along the Qinghai-Xizang Highway: Acta Geographica Sinica, v. 34,: pp. 18-32.

Wang, J. T., 1981, On the fundamental characteristics of the steppe vegetation in Xizang Plateau. in Geological and Ecological Studies on QinghaiXizang Plateau: Beijing, Sciece Press and Now York, Breach, Gorgon, pp. 1929-1936.

Wang, J. T. and Wang P. X., 1980, Relation between sea level changes and climatic fluctuations in east China since Late Pleistocene: Acta Geographica Sinica, v. 35, pp.99-312 (in Chinese).

Wang, L. and Wang, P.X., 1990, Late Quaternary paleoceanography of the South China Sea: Glacial-intergracial contrasts in an enclosed basin: Paleoeanography v. 5, pp. 77-90.

Wang, N., 1984, Geomorphological studies in China, in Zheng, X., ed. Geography in China: Beijing, Science Press, pp. 17-32.

Wang, P. X., Wang, L. J., Bian Y. H. and Jian Z. M., 1995, Late Quaternary paleoceanography of the South China Sea: surface circulation and carbonate cycles: Marine Geology, v. 127, pp. 145-165.

Wang, S. and Li, J., 1991, Late Cenozoic lake sediments in China, in T.S Liu ed., Quaternary geology and environment in China: Beijing, Science Press, pp. 49-57.

Winkler, M. G. and Wang, P. K., 1993, The Late Quaternary vegetation and climate of China. in H. E. Wright, Jr.,J. E. Kutzbach, T. Webb, W. F. Ruddiman, F. A. Street-Perrott and P. J. Bartlein, eds. Global Climate since the Last Glacial Maximum: Minneapolis, University of Minnesota Press, pp. 221-258.

Wu, Z., Wang, X., Liu, F. and Zhu, F., 1980, Vegetation of China, Beijing, Science Press, pp. 180-390.

Xiao, J., Inouchi, Y., Kumai, H, Yoshikawa, S., Kondo, Y., Liu, T. S., and An, Z. S., 1997, Aeolian quartz flux to lake Biwa, Central Japan, over the past 145,000 years: Quat. Res., v. 48, pp. 48-57. 
Xue, C. and Cheng, G., 1989, Shelly ridges in west coast of Bohai Sea and Holocene Yellow River Delta system, in Z. Yang and H. Lin, eds., Quaternary processes and events in China offshore and onshore areas: Beijing, China Ocean Press, pp. 117-125 (in Chinese).

Xue, C., Ye, Z., and He, Q., 1991, Holocene coastal sedimentation of China, in Liu T. S. ed., Quaternary geology and environment in China: Beijing, Science Press, p. 64-72.

Xue, C., Zhu, X., and Lin. H., 1995. Holocene sedimentary sequence, foraminifera and Ostracoda in west coastal lowland of Bohai Sea, China:. Quat. Sci. Rev., v. 14, pp. 521-530.

Yan, F. H., Ye, Y.Y., Mai, X. S., and Liu, Y.X., 1981, On the environment and geological age of two cores in Beijing region from sporo-pollen analysis: Seismology and Geology, v. 3, pp. 52-56 (in Chinese).

Yan, Z. and Petit-Maire, N., 1994, The last $140 \mathrm{ka}$ in the Afro-Asian arid/semi-arid transitional zone: Palaeogeogr. Palaeoclimat., Palaeoecol., v. 110, pp. 217-223.

Yang, D. Y., 1991, Influence of climate and sea-level changes on the alluvial processes of the mid-lower reaches of the Yangtze river in the last 10,000 years, in Liu T. S. ed., Quaternary geology and environment in China: Beijing, Science Press, pp. 337-342.

$\mathrm{Yu}$, G. and Qin, B., 1997, Holocene temperature and precipitation reconstructions and monsoonal climates in eastern China using pollen data: Paleoclimates, v. 2, pp. 1-32.

Zhang, D., 1984, Synoptic-climatic studies of dust fall in China since historical time: Scientia Sinica (Series B), v. 17, pp. 825-836.

Zheng, B. X. and Shi, Y. F., 1982, Glacial variation since late Pleistocene on the Qinghai-Xizang (Tibet) plateau of China. in Liu T. S. ed., Quaternary geology and environment in China: Beijing, China Ocean Press, (in Chinese), pp. 161-166.

Zheng, M. P., Liu, W., Xiang, and Jian, Z. C., 1983, Salt lake in Xizang (Tibet): Acta Geologica Sinica, v. 57, pp. 185-194.
Zheng, S. H. and Han, D. F., 1991, Quaternary mammals of China, in Liu T. S. ed., Quaternary geology and environment in China: Beijing, Science Press, pp. 101-114.

Zheng, Z., 1991, Répartition de Dacrydium (Podocarpaceae) au Quaternaire Supérieur en Chine méridionale d'après l'analyse pollinique: Palynosciences (APLF), v. 1, pp.167-186.

Zheng, Z., 1995, Quaternary distribution of Sonneratia in southern China: Journal of Sunyatsen University, v. 4, pp. 35-41 (in Chinese).

Zheng, Z. and Lei, Z. Q., 1998, A 400,000 year record of vegetational and climatic changes from a volcanic basin, Leizhou Peninsula, Southern China: Palaeogeogr., Palaeoclimat., Palaeoecol. (in press).

Zhou, Y., Qiu, G. and Guo, D., 1991, Changes of permafrost in China during Quaternary, in Liu T. S. ed., Quaternary geology and environment in China: Beijing, Science Press, Beijing, pp. 86-94.

Zhu, Z. D., 1980, Desert of China (1-2): Beijing, Science Press, (in Chinese).

Zhuo Zheng, received phD. from the University of Montpellier II des Sciences et Techniques du Languedoc of France in 1986, is an Associate Professor of the Zhongshan University, China. His recent researches are mainly on Late Quaternary palynology, paleoclimatology and biogeography particularly in tropical and subtropical areas of southeastern China.

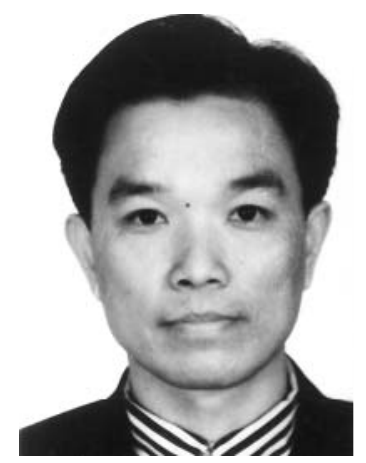

\section{Hutchison 'Young Scientist' Fund}

William Watt Hutchison, "Hutch" to his many friends around the world, was a Scots-born Canadian geologist who served Canada and the IUGS in myriad dynamic and creative ways. Most notably, he served as the IUGS Secretary General (1976-1980) at a pivotal time in its history, and as IUGS President (1984-1987). The same boundless energy, enthusiasm, skill in communications, and ability to foster teamwork that characterized his work with the IUGS also carried him to preeminent scientific administrative positions in the Canadian Government, where he served as Director General of the Geological Survey of Canada and as Assistant Deputy Minister of Earth Sciences. His distinguished career was terminated in 1987 by his untimely death at the age of 52, following a painful struggle with cancer.

One of Hutch's last wishes was to establish under IUGS auspices a memorial foundation intended to promote the professional growth of deserving, meritorious young scientists from around the world by supporting their participation in important IUGS-sponsored conferences. The first 3 beneficiaries of the Hutchinson "Young Scientist Foundation" attended the 28th International Geological Congress (IGC) in Washington, D.C., in 1989.

Currently, income earned as interest on the Hutchison fund is insufficient to sustain comparable grants every four years without seriously eroding the principal. For that reason, the IUGS made no grants from the fund for the 30 th IGC, preferring instead to strengthen the fund by allowing it to earn interest for a longer period of time and by appealing for donations from the international geologic community. It is expected that grants from the fund will again support deserving young scientists to attend the 31st IGC in the year 2000. The Hutchison "Young Scientist Foundation" is a worthy cause that honors a fine, caring man and a distinguished, public-spirited scientist and administrator. The foundation also celebrates and promotes those things that gave Hutch the most professional satisfaction: geology, international scientific collaboration, and stimulating young minds.

The IUGS welcomes contributions to the Hutchison "Young Scientist Foundation." Please send donations to:

Dr. John A. Reinemund
P.O. Box 890
Leesburg, VA 20178 USA
Fax: +1 7037774463
Tel: +1 7037771491

Checks in US dollars or Visa/Mastercard (please include account number and expiration date) are preferred in order to avoid the high cost of currency conversions. Residents of the U.S.A. are reminded that charitable gifts of this nature are tax deductible. 